\title{
EUGENICS QUARTERLY
}

Published by the AMERICAN EUGENICS SOCIFTY, Inc. 230 Park Avenue, Nem York i7, N. Y.

Vol. 14, No. 4

December 1967

\section{Contents}

Some Observations on Recent Changes in American Fertility Based on Sample Survey Daia, David Golberg

The Lvel of Nonwhite Feriility in the United States, I930 and Ig2o, Melvin Zelnik

Colorblindness Among Korean Students, Yung Sun Rang, Suk Woo Lee, Suzy, Park, and Wan Kyoo Cqo

Some Effects of Being Able to Control Sex of Offspring, Edward Pohlman

The Oneida Community Eyperiment in Stiripiculture, Hilda Herrick Noyes and George Wallingford Noyes

Brief Reporls

A Note on Changes in Age at Marriage of Females and Their Effect on the Birth Rati in India, Prem P. Talwar
Genetics and Schizophrenia, Arnold R. Kaplan

The Concept of Adaptatioa in the Study of Human Populaiions, Joel Cracraft

Reply to Cracrafi's Comments, Pete E. Lestrel

\section{Communication}

Report on a Conference: The Tiansmissinn of Schizophrenia, Arnold R. Kaplan

Book Reviews: Demography, Clyde V. Kiser, Genetics, Arnold R. Kaplan

Beriodical Abstracts

Genetics, Gordon Allen

\section{EDITORIAL BOARD}

Frederick Osborn, Chairman

Gordon Allen

Frank Lorimer

Richard H. Osborne, Acting Editor

Consulting Editors: Jan BööK, F. Clarke Fraser

Glyde V. Kiser, Leighton van Nort, L. D. Sanghvi, Jean Sutter

EUGENICS QUARTERLY is published March, June, September, and December at $3110 \mathrm{Elm}$ Ave., Baltimore Ir, Md., for the American Eugenics Society, Jnc., Room 1523, 230 Park Avenue, New York I7, N. Y. Eugenics Quarterly is mailed to all members of the Society and to non-member subscribers. Subscription price, $\$ 7.00$ per year. Inquiries about membership in the American Eugenics Society should be addressed to the Secretary of the Society, 230 Park Avenue, New York 17, N. Y. Single copies, \$2 plus postage. Second-class postage paid at Baltimore, Maryland (C) I 961 by the American Eugenics Societr, Inc. All rights reserved. 


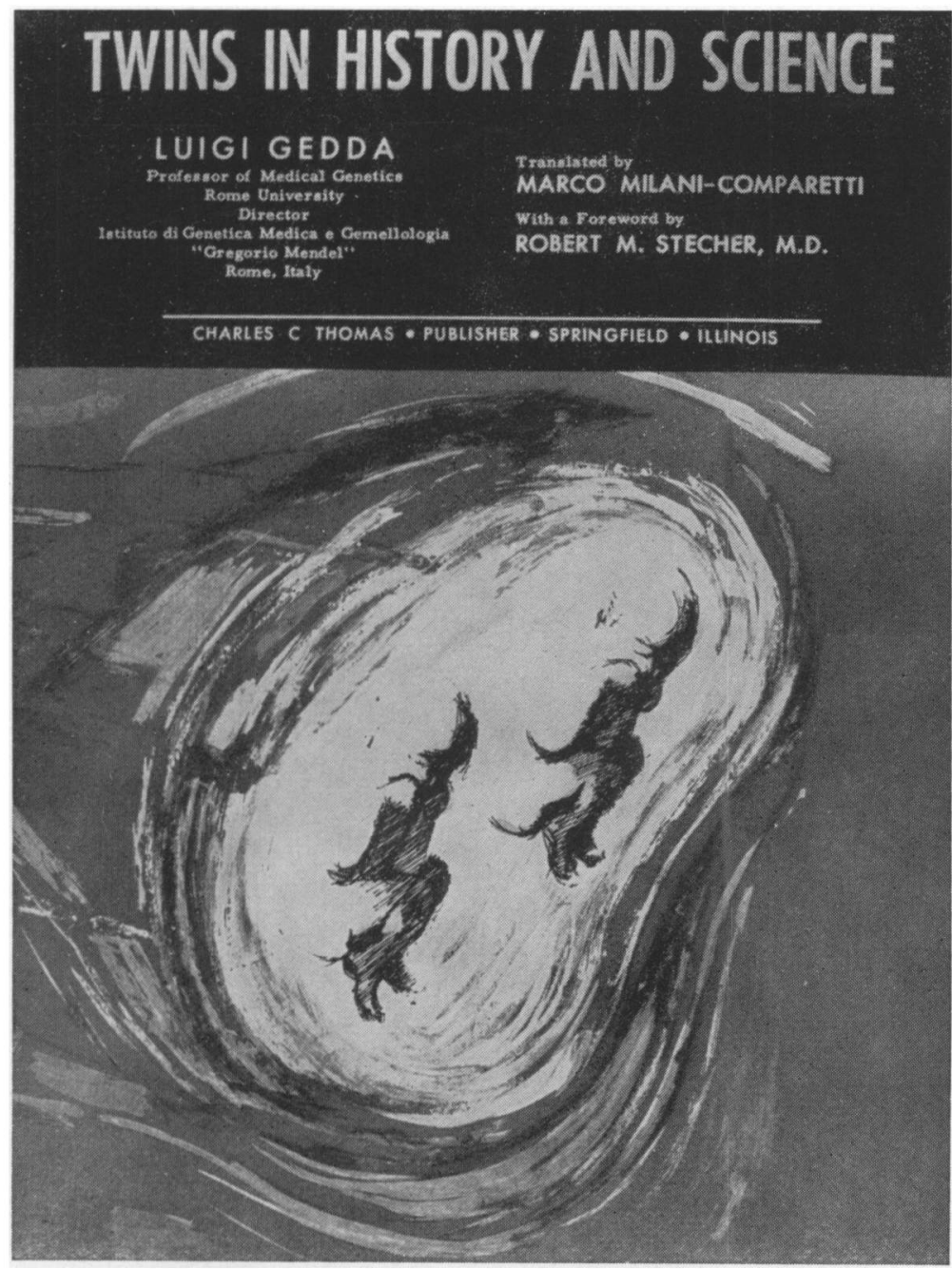

\section{CONTENTS}

Twins in Mythology and the Arts

History and Science of Twins

Twins in Plant and Animal Life

Frequency of the Twinning Phenomenon

Etiologic Background Factors in Twinning

The Genetics of Twinning

Embryology of Twinning Twin Pregnancy : Its Physiology and Pathology Anatomical Studies of Twins

pages 240

154 illustrations

IX color tables

$\$ 12,50$

\section{TWINS IN HISTORY AND SCIENCE}

"Professor Gedda has successfully assembled the world's knowledge of twins and of twinning. He has presented the data completely, he has discussed it authoritatively and he has produced an inspiring book which promises to arouse interest anew in the English speaking world in the subject of twins".

From the Foreword by ROBERT M. STECHER, M. D.

CHARLES C THOMAS - PUBLISHER - SPRINGFIELD - ILLINOIS 


\title{
Ling \\ Proceedings International Congress of Human Genetics
}

\author{
Volume I Introduction and History of the Congress \\ From Mendelian to Molecular Genetics in Man \\ Population Genetics, Mutation and Natural Selection \\ Methods in Human Genetics \\ Twins and Human Genetics \\ Inheritance of Normal Quantitative and Qualitative Human Traits \\ Microbial and Biochemical Genetics
}

\author{
Volume II Genetic and Biochemical Aspects of Human Serum Factors \\ Blood Groups \\ Clinical Genetics \\ Chromosome Genetics \\ Cancer, Leukemia and Ionizing Radiations
}

$\begin{array}{ll}\text { Volume III } & \text { Malformations } \\ \text { Dermatoglyphics } \\ \text { Neurological Genetics } \\ \text { Psychological and Behavioral Genetics } \\ \text { Psychiatric Genetics } \\ \text { Hereditary Diseases of the Sense Organs } \\ \text { Genetic Counseling and Public Health }\end{array}$

Lit. $22.000-\$ 36.00$

(I volume: Lit. $10.000-\$ 16.00$ )

Published by «Istituto Gregorio Mendel»-Rome rg63 